\title{
Covid-19: South Korea relaxes social distancing after the number of new cases drops below 10 a day
}

\author{
Elisabeth Mahase
}

The BMJ

South Korea has announced it will begin easing social distancing measures from 6 May, as the number of new confirmed cases dropped to very low levels.

Prime Minister Chung Sye-kyun told the public that the government will allow businesses to reopen in phases and gatherings and events can take place as long as they follow disinfection guidelines. Parks, libraries, schools, and other public facilities could also start to reopen in phases. ${ }^{1}$

However, citizens have been reminded by the Korea Centers for Disease Control and Prevention (KCDC) to remain cautious during their daily activities.

In an alert on 5 May, the KCDC said, "'Distancing in daily life,' which will take effect tomorrow, does not mean we will return to the same routine as before, but to the 'new normal' in which people will practise infectious disease prevention rules on a regular basis." ${ }^{2}$

It said the country will "carry out social and economic activities while simultaneously practising infectious disease prevention measures" and warned that "we can return to "enhanced social distancing' at any time if the situation worsens."

As of 5 May, South Korea has reported 10804 confirmed covid-19 cases, including 1102 that were imported. Of these, 9283 cases have been discharged from isolation, and the newly confirmed cases have dropped to under 10 per day ( 3 on 5 May, 8 on 4 May).

Despite South Korea experiencing an early burst of cases and becoming the worst affected country outside of China in mid-February, ${ }^{3}$ it has managed to keep the deaths to a low level with a total of 254 ( 5 May) or 4.92 deaths per million population.
This compares with 29079 deaths in Italy (481.19 deaths per million) and 28734 in the UK (432.16, as of 5 May).

The country has done this without putting its citizens in lockdown. Instead it relied on widespread and convenient testing, and strict isolation measures including tracking people using credit card information to ensure they were complying. ${ }^{4}$ The easing of social distancing also follows an investigation into re-confirmed covid-19 cases. In April, the KCDC reported that hundreds of people who had recovered from covid-19 and tested negative, had later tested positive. This raised concerns over the potential for people to be reinfected with the virus, however these reconfirmed cases have since been deemed as false positives.

Oh Myoung-don-who leads the central clinical committee for emerging disease control in South Korea—said the tests had detected the ribonucleic acid of the dead virus, and that these seemingly relapsed cases were from the technical limits of such testing.

Kim C. South Korea to relax social distancing rules further, starting May6. 3 May 2020 Reuters. www.reuters.com/article/us-health-coronavirus-southkorea/south-korea-to-relaxsocial-distancing-rules-further-starting-may-6-idUSKBN22F06C

2 KCDC. Updates on covid-19 in Republic of Korea. 5 May 2020. www.cdc.go.kr/board/ board.es? $\mathrm{mid}=\mathrm{a} 30402000000$ \& bid $=0030$.

3 Day M. Covid-19: surge in cases in Italy and South Korea makes pandemic look more likely. BMJ 2020;368:m751. 10.1136/bmj.m751 32098875

4 Jae-hee C. South Korea's best method of tracking covid-19 spread: credit card transactions. Korea Herald. 9 April 2020. www.koreaherald.com/view.php? $\mathrm{ud}=20200408000918$.

Published by the BMJ Publishing Group Limited. For permission to use (where not already granted under a licence) please go to http://group.bmj.com/group/rights-licensing/ permissions 